\title{
APPLYING THE URBAN FUTURES METHODOLOGY FOR EVALUATING THE METROPOLITAN DEVELOPMENT IN TIMISOARA, ROMANIA
}

\author{
Bogdan Nadolu' ${ }^{1}$ (i) \\ Delia Nadolu ${ }^{2}$
}

DOI: https://doi.org/10.31410/LIMEN.2019.59

\begin{abstract}
Timisoara is one of the first five city from Romania, an important Growing Pole in DKMT Euro-region. Timisoara is also into an inner-periphery, among four European capital, Bucharest, Belgrade, Budapest, and Wien that are less than $600 \mathrm{~km}$ away. After the political change from 1990 the entire country was massive affected by economic, social, cultural and juridical reconfiguration. During 1990s the city has to deal with a significant population lose, due urban sprawl, negative birth rate and outmigration. Nowadays the municipality try to strengthen the Timisoara's resilience by developing the metropolitan area. This paper present how can be used the Urban Futures Methodology to evaluate the sustainability of public policies, actions, measures applied toward the transform the city into a metropole. This work was supported by a grant of the Romanian National Authority for Scientific Research and Innovation, CCCDI-UEFISCDI, project number 66/2017 COFUND-ENSUF-3S RECIPE (1), within PNCDI III.
\end{abstract}

Keywords: Urban resilience, Inner periphery, Urban governance.

\section{INTRODUCTION}

$\mathrm{O}$ ne of the main benefits of the fall of the Iron Curtin was the opening of the boundaries and the massive migration from East to West. A direct consequence of the restauration of the free circulation of the people was the depopulation of the Eastern countries. Almost all post-socialist cities from Central and Eastern Europe that are inner peripheries has known a significant process of shrinkage. The main cause was obviously the significant difference of living condition between West and East Europe. Another issue was related by the urban development, more strategic and functional in West comparatively with forced industrialization in East (Szelenyi). Thus, almost all medium and large cities in Romania, including Timisoara were developed over the historical configuration, with a non-functional mix of houses on ground neighborhoods and ten level block flats, with inadequate structure of urban services and utilities and, in many causes overcrowded due to extensive industrial facilities and demand of working forces. In this context, due to 1990s' Timisoara has lost around 50.000 inhabitants by urban sprawl toward nearby villages, by negative birth rate (after the liberalization of the abortion) and by outmigration. After 2010 the city has recovered a part from these demographic declines and now the official population volume is relatively stable at 330.000 inhabitants (Figure 1).

Urban shrinkage is nowadays a common stage into the evolution of medium and large cities all over the globe. Following the official statistics in Europe, in particular, 38 out of 100 cities have less population today than they did 25 years ago, before the fall of the Berlin Wall. By the mid2000s, the share of shrinking cities across Europe's larger urban areas with 200,000 residents and above had reached 42\% (Turok \& Mykhnenko, 2007; Mykhnenko \& Turok, 2008). Into the

\footnotetext{
1 West University of Timisoara, Bd.V.Parvan, no 4, Timisoara, Romania

2 West University of Timisoara, Bd.V.Parvan, no 4, Timisoara, Romania
} 
last quarter of century, the population loss, socio-economic decline or stagnation have had a profound impact on more than 2,700 municipalities in the European Union alone. Many cities, situated in close proximity to powerful centers of economic growth and cultural vibrancy, find themselves in their shadows - at the inner periphery - of regional, national, and global developmental trends (ESPON, 2013; Pike et al., 2016). During the last decade into the academic and public discourse it was made a great progress in recognizing the causes of the socio-economic inner peripherality, and in documenting the complexity of its consequences (see Boom \& Mommaas, 2009; Ganser \& Piro, 2012; Grossman et al., 2013; Martinez-Fernandez et al., 2012; Pallagst et al., 2014; Oswalt, 2005). A good deal of concerted action has already been taken on the part of many governments and local authorities in Europe and beyond, reacting to the most immediate, visible, and damaging consequences of urban shrinkage (Haase et al., 2016; Langner \& Endlicher, 2007; Neill \& Schlappa, 2016; Richardson \& Nam, 2014).

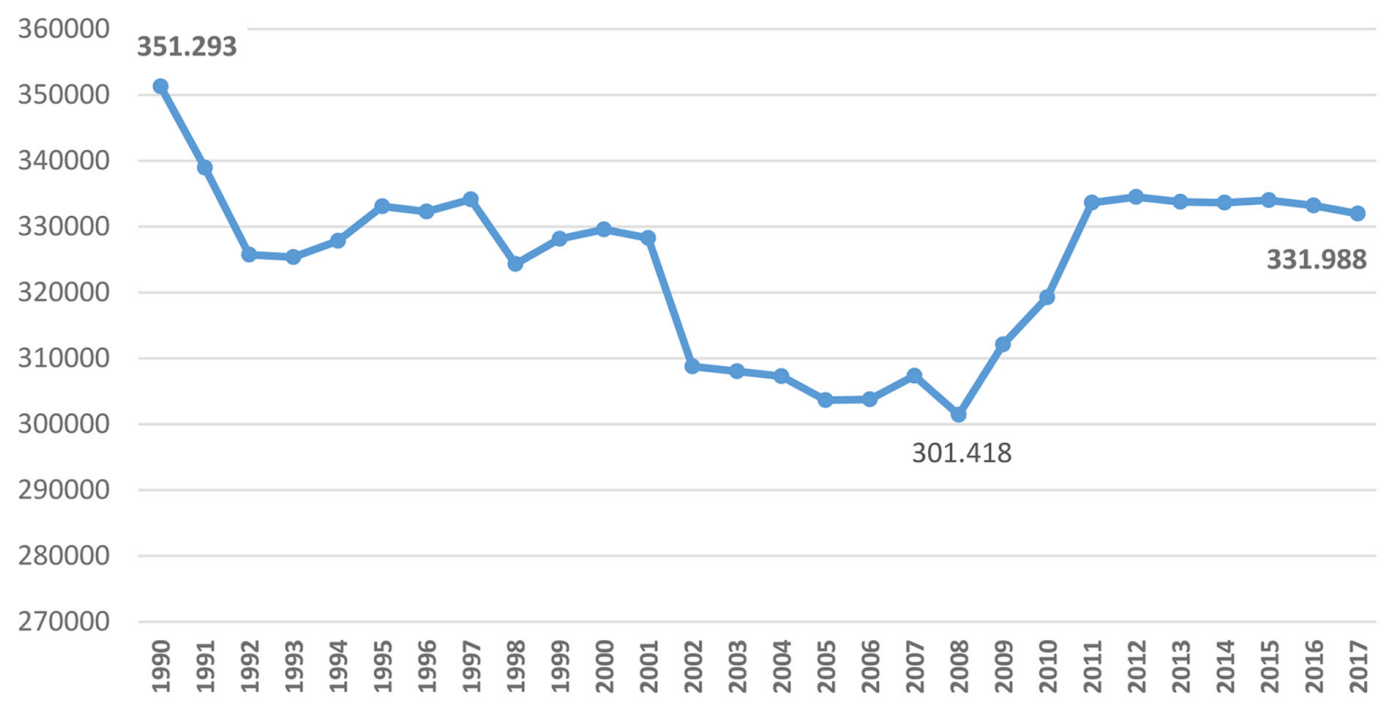

Figure 1 The evolution of the Timisoara's population after the 1989

Sources: Romanian National Institute of Statistics

\section{METHODOLOGY}

As an inner-periphery the further natural development of the Timisoara is limited by three big European capitals that are neighbor: Bucharest, Belgrade and Budapest. Starting from 2000 the Timisoara City Hall has prepared the Metropolitan master plan for defining a clear goal of urban planning. Since than there were develop several actions and projects to connect the city with the new residential neighborhoods, and to implement various urban services into these areas. Even the Timisoara's aerosolization can be considerate a very legitime purpose for further development of the city its implementation is not a surely and sustainable approach. Thus, for the evaluation of the viability of the development of the metropolitan area in Timisoara as a direct measure against the population decline for an inner periphery city, we have applied the Urban Future Method into the project 3S RECIPE Smart Shrinkage Solutions. Fostering Resilient Cities in Inner Peripheries of Europe financed by a grant of the Romanian National Authority for Scientific Research and Innovation, CCCDI-UEFISCDI, project number 66/2017 COFUND-ENSUF-3S RECIPE (1), within PNCDI III.

Following the authors description, "the Urban Futures Method aims to broaden the way we thing about the form and function of urban development and regeneration by focusing on the 
likely long-term performance of today's urban design solution and their associated risks. The Urban Futures Method is primarily for use when the stakeholders involved in implementing a sustainability solution consult together to make decisions as part of the redevelopment process. The greatest value comes when there is an opportunity for all partners involved to exchange knowledge and ideas and to create better solutions based upon their combined knowledge." (Lombardi et all, 2012). The UFM involve a group decision activity with the following steps: (i) identify a sustainability solution for an urban problem and its intended benefit (solution-benefit pair) for analysis; (ii) identify the conditions necessary for this benefit to be delivered; (iii) determine the performance of the necessary conditions in the future - will the necessary condition be in place? (iv) determine the resilience of the solution benefit pair to future change; (v) decide on the appropriate course of action: to implement the solution as is, adapt it to address vulnerabilities, or replace it with an alternative solution. Depending of the group structure the output can have different profile, but as the participants are mostly stakeholders or people connected with the analyzed topic the results remain into some frame.

The smart shrinkage solution analyzed by UFM may be strategic, as principle or detailed, focus on a specific target related to population decline and associated consequences. Whatever the short-term effect of a given solution, policy-makers must adopt a longer-term perspective to ensure its continued performance throughout its intended lifespan, despite changing conditions. The question to ask is, thus: Will today's smart shrinkage solutions deliver their intended benefits over a 40-year regeneration cycle, typically used for planning investment and development proposals? During this project, we have tested the likely future performance of each urban development and regeneration-related 'smart shrinkage solution-benefit pair' - that is, actions taken today in the name of sustainable urban development - in a series of possible future scenarios for the year 2060. If a proposed solution delivers a positive legacy, regardless of the future against which it is tested, then it can be adopted with confidence. Four plausible but distinct future scenarios were included into our analysis (see Lombardi et. al., 2012: Table 2). A summary of these four global archetypal urban future scenarios is provided below:

(i) The New Sustainability Paradigm: equity and sustainability. An ethos of "one planet living” facilities a shared vision for more sustainable living and a much-improved quality of life. New socio-economic arrangements result in changes to the character of urban industrial civilization. Local is valued but global links also play a role. A sustainable and more equitable future is emerging from new values, a revised model of development and the active engagement of civil society.

(ii) Policy Reform: economic growth with greater equity. Policy Reform depends on comprehensive and coordinated action for poverty reduction and environmental sustainability, negating trends towards high inequality. The values of consumerism and individualism persists, creating a tension with policies that priorities sustainability.

(iii) Market Forces: competitive, open global market. Market Forces relies on the self-competitive markets. Current demographic, economic, environment and technological trends unfold without major surprise. Competitive, open and integrated markets drive world development. Social and environmental concerns are secondary.

(iv) Fortress world: protection and control of resources. Powerful individuals, groups and organizations develop an authoritarian response to the threats of resources scarcity and social breakdown by forming alliances to protect their own interests. Security and defensibility of resources are paramount for these privileged rich elites. An impoverished majority exists outside the fortress. Policy and regulation exist but enforcement may be limited. Armed forces act to impose order, protect the environment and prevent a societal collapse. 
Into the 3S RECIPE project it was analyzed the urban resilience of the Timisoara's metropolization by Urban Future Method. For this it was organized one workshops with 16 local stakeholders from Timisoara City Hall, Romanian Development Agency, National Institute of Statistics, experts for the urban commission of County Council, Timisoara Intercultural Institute NGO, Vitamina NGO and West University of Timisoara. The starting point was the identification of the municipality response to the population decline due to 1990s. In Table 1 there are presented the identified policies responses for each cause of depopulation:

Table 1. Policies response of the Timisoara's Municipality to the causes of the depopulation during 1990s.

\begin{tabular}{|l|l|}
\hline Causes & Policies responses \\
\hline out-migration & $\begin{array}{l}\bullet \text { economical facilities for investors; } \\
\bullet\end{array}$ \\
remain in the city after graduate \\
\hline negative birth-rate & $\bullet$ national financial support for new born child \\
\hline urban sprawl & $\bullet$ Metropolitan Development Plan (2000) \\
\hline
\end{tabular}

Source: author work

The UFM was applied on the evaluation of the actions, projects and interventions implemented by the Timisoara City Hall toward the metropolization of the city. For this development the participants to the workshop have identified several benefits, such: urban planning and organization at a large scale, preserving local identity, access to social services for a large amount of population from closer villages, implementing of the principle of urban ecology, the improving of quality of life, the diversification of the occupation (due to a more developed labor market), the economic development, the extension of the infrastructure and of the transportation system and, last but not least, the diversification of the leisure activities. For each of these benefits the participants to the workshop have identified one afferent necessary condition that contribute to the existence of these benefits. Besides the ten necessary conditions directly related with the ten benefits synthetized for the developing of the metropolitan area, it was formulated a supplementary condition related by the increasing of the volume of population. It is obviously that if the Timisoara as an urban inner-periphery will don't attract more inhabitants the metropolitan plan is not sustainable.

Into the second part of the workshop it was analyzed each necessary condition from the perspective of the fourth archetypally scenario: The New Sustainability Paradigm, Policy Reform, Market Forces and Fortress World. The participants have to mark with yes/no/maybe and to formulate a short argue for each condition into the perspective of each scenario. It was obtained a grid where can be observed what it will happening with the Timisoara's metropolization if in the next 40 years the city will evaluate for one of other from these scenarios. As can be observed into the Table 2 the Policy Reform Scenario is the most adequate future evolution of the city for implementing the metropolization process, since the Fortress World is less adequate. The option for one or other of these future evolutions is not complete under the municipality control, they are depending also by several regional, national and euro-regional factors. Despite these, if there are clear sign for going toward others scenario with a less support for the developing of the metropolitan area the City Hall and other stakeholders will have at least the possibility to reconfigure the development strategy, and to reduce the allocated resources for this less sustainable project. 


\begin{tabular}{|c|c|c|c|c|}
\hline & New sustainability paradigm & Policy reform & Market Forces & Fortress world \\
\hline $\begin{array}{l}\text { NC0. Increasing the } \\
\text { population volume }\end{array}$ & $\begin{array}{l}\text { YES- Increasing the } \\
\text { population volume would be } \\
\text { facilitated by this scenario } \\
\text { aiming a better quality } \\
\text { of life and active civic } \\
\text { participation of citizens }\end{array}$ & $\begin{array}{l}\text { YES - because this scenario } \\
\text { aims to reduce poverty and } \\
\text { social inequality, promoting } \\
\text { welfare (although such } \\
\text { living conditions may } \\
\text { reduce the birth rate) }\end{array}$ & $\begin{array}{l}\text { MAYBE - depending } \\
\text { on the market forces } \\
\text { dynamics, population } \\
\text { may grow or decreases }\end{array}$ & $\begin{array}{l}\text { NO - this scenario } \\
\text { promotes a minority with } \\
\text { access to the resources } \\
\text { and drives away the poor } \\
\text { majority }\end{array}$ \\
\hline $\begin{array}{l}\text { NC1. Linking of } \\
\text { the development } \\
\text { strategies to } \\
\text { generate synergies } \\
\text { at the metropolitan } \\
\text { area }\end{array}$ & $\begin{array}{l}\text { YES - raising awareness of } \\
\text { public sphere and prioritizes } \\
\text { solving common issues/ } \\
\text { social problems into an } \\
\text { integrative approach. } \\
\text { The correlation of the } \\
\text { Timisoara's and nearest } \\
\text { villages' strategies generate } \\
\text { a sustainable urban } \\
\text { ecosystem. }\end{array}$ & $\begin{array}{l}\text { YES - the only way to } \\
\text { gather/focus the resources } \\
\text { and achieve social } \\
\text { integrated development on } \\
\text { all levels so that the entire } \\
\text { metropolitan population to } \\
\text { can benefits of a better life }\end{array}$ & $\begin{array}{l}\text { MAYBE - depending } \\
\text { on the interest of } \\
\text { actors (playing on the } \\
\text { free market), could } \\
\text { appear divergent } \\
\text { mechanisms favourable } \\
\text { for speculation which } \\
\text { contravene common } \\
\text { strategies }\end{array}$ & $\begin{array}{l}\text { NO - in this scenario } \\
\text { resources are available } \\
\text { only for a privileged } \\
\text { rich elite. This elite } \\
\text { will promote only its } \\
\text { agenda, independent by } \\
\text { the common policies } \\
\text { and regulations/social } \\
\text { development. }\end{array}$ \\
\hline $\begin{array}{l}\text { NC2. Strengthening } \\
\text { local values, } \\
\text { construction of an } \\
\text { integrative spirit } \\
\text { and a metropolitan } \\
\text { mentality }\end{array}$ & $\begin{array}{l}\text { YES - Timișoara has } \\
\text { a green identity, being } \\
\text { called „The City of Roses” } \\
\text { Timișoara's cosmopolitan } \\
\text { identity should be } \\
\text { preserved and transformed } \\
\text { into a more inclusive, } \\
\text { metropolitan identity. All } \\
\text { these elements are favorable } \\
\text { for a sustainable harmony } \\
\text { cohabitation/conviviality } \\
\text { with an active civic society } \\
\text { and an increasing quality } \\
\text { of life. }\end{array}$ & $\begin{array}{l}\text { MAYBE - depends on the } \\
\text { development of civil society } \\
\text { and on the collaboration } \\
\text { between the public } \\
\text { institutions, political actors } \\
\text { at the central level, local } \\
\text { administration and local/ } \\
\text { regional NGO's. The reform } \\
\text { of the public policies can } \\
\text { be oriented even at micro } \\
\text { level (with promoting of } \\
\text { the Timisoara's spirit) or at } \\
\text { macro level (with promoting } \\
\text { European values) }\end{array}$ & $\begin{array}{l}\text { MAYBE -if the } \\
\text { newcomers and the } \\
\text { new economic agents } \\
\text { will use and promote } \\
\text { the local brands, local } \\
\text { specificity. Market } \\
\text { forces could increase the } \\
\text { local entrepreneurship } \\
\text { competitively or } \\
\text { the multinational } \\
\text { corporations. }\end{array}$ & $\begin{array}{l}\text { YES - The focus on } \\
\text { preserving local identity, } \\
\text { Timisoara's values and } \\
\text { habits, will highlight } \\
\text { the differences/gaps at } \\
\text { the metropolitan area's } \\
\text { borders, and could } \\
\text { increase the isolation of } \\
\text { the metropolitan area. }\end{array}$ \\
\hline $\begin{array}{l}\text { NC3. Expand and } \\
\text { diversification of } \\
\text { social services, } \\
\text { education and health } \\
\text { facilities }\end{array}$ & $\begin{array}{l}\text { YES - poverty reduction, } \\
\text { increasing the quality of } \\
\text { life and environmental } \\
\text { sustainability could be } \\
\text { achieved by coherent } \\
\text { social strategies and policy } \\
\text { offering diversification of } \\
\text { social services, education, } \\
\text { health facilities, social } \\
\text { economy offer (depending } \\
\text { on the community needs } \\
\text { and problems). }\end{array}$ & $\begin{array}{l}\text { YES-a shared vision } \\
\text { of a more sustainable } \\
\text { environment and improved } \\
\text { quality of life will } \\
\text { respond to the need and } \\
\text { diversification of social } \\
\text { services. The dynamics } \\
\text { of metropolitan realities } \\
\text { will claim a permanent } \\
\text { adaptation of the social } \\
\text { services to improve the } \\
\text { quality of life and to ensure } \\
\text { a sustainable environment. } \\
\end{array}$ & $\begin{array}{l}\text { MAYBE - if the } \\
\text { social services private } \\
\text { providers will get a profit } \\
\text { by diversifying these } \\
\text { services. }\end{array}$ & $\begin{array}{l}\text { NO - the privileged } \\
\text { elite have no interest } \\
\text { in expanding social } \\
\text { services, or to diversify } \\
\text { social resources and } \\
\text { social services for the } \\
\text { fortress outsiders }\end{array}$ \\
\hline $\begin{array}{l}\text { NC4. Developing } \\
\text { housing policies }\end{array}$ & $\begin{array}{l}\text { YES - the active } \\
\text { engagement of civil society } \\
\text { will continuously remind } \\
\text { and prioritizes on the } \\
\text { public agenda the need of } \\
\text { a coherent housing policy } \\
\text { aiming an equitable future. }\end{array}$ & $\begin{array}{l}\text { YES - the metropolitan } \\
\text { area will continuously } \\
\text { need a housing policy } \\
\text { reform, with focus on } \\
\text { better living conditions } \\
\text { to reduce poverty and } \\
\text { well-integrated regulation } \\
\text { to ensure environmental } \\
\text { sustainability. The housing } \\
\text { policy is directly associated } \\
\text { with the development, } \\
\text { mobility, environment } \\
\text { youth, education policies. }\end{array}$ & $\begin{array}{l}\text { YES - the land owners } \\
\text { and the real estate } \\
\text { developers will compete } \\
\text { for building houses } \\
\text { with increased living } \\
\text { conditions and residential } \\
\text { areas well equipped } \\
\text { (playing grounds, } \\
\text { recreational facilities, } \\
\text { transportation and so on) }\end{array}$ & $\begin{array}{l}\text { NO - the powerful groups } \\
\text { will not be interested to } \\
\text { support the costs of a } \\
\text { housing policy }\end{array}$ \\
\hline $\begin{array}{l}\text { NC5. The transfer } \\
\text { of some urban } \\
\text { functions to } \\
\text { periphery (of the } \\
\text { metropolitan area) }\end{array}$ & $\begin{array}{l}\text { YES - a sustainable } \\
\text { solution of development } \\
\text { consists in the availability } \\
\text { of urban functions (would } \\
\text { be less time consuming and } \\
\text { will reduce the pollution } \\
\text { and the transportation } \\
\text { costs). Also, the suburbs } \\
\text { will develop real social life } \\
\text { and would be transformed } \\
\text { from the ,residential } \\
\text { dormitory” into a ,living/ } \\
\text { vivid social community”. }\end{array}$ & $\begin{array}{l}\text { YES - there is a need for } \\
\text { the stakeholders' consensus } \\
\text { towards a master plan } \\
\text { centered on the urban } \\
\text { functions needed by the } \\
\text { metropolitan areas }\end{array}$ & $\begin{array}{l}\text { MAYBE - uncontrolled } \\
\text { investments could } \\
\text { produce irreversible } \\
\text { effects on the community } \\
\text { life. Urban functions at } \\
\text { the peripheries can have } \\
\text { or not have a potential } \\
\text { competitivity comparable } \\
\text { with those of the city } \\
\text { center }\end{array}$ & $\begin{array}{l}\text { NO - the privileged } \\
\text { group will tend to oppose } \\
\text { the transfer of the urban } \\
\text { functions at/outside the } \\
\text { fortress borders }\end{array}$ \\
\hline
\end{tabular}




\begin{tabular}{|c|c|c|c|c|}
\hline & New sustainability paradigm & Policy reform & Market Forces & Fortress world \\
\hline $\begin{array}{l}\text { NC6. A more } \\
\text { diversified work } \\
\text { opportunity }\end{array}$ & $\begin{array}{l}\text { NO - caring for a } \\
\text { sustainable living and effort } \\
\text { for improving the quality } \\
\text { of life assume rejection of } \\
\text { specific work domains and } \\
\text { limit the diversity of work } \\
\text { opportunities that are not } \\
\text { eco-friendly. }\end{array}$ & $\begin{array}{l}\text { MAYBE-work } \\
\text { opportunities may } \\
\text { diversify in social services } \\
\text { area, in education and } \\
\text { health care, but also new } \\
\text { domains that can facilitate } \\
\text { the work integration for } \\
\text { vulnerable categories } \\
\text { of population (social } \\
\text { entrepreneurship, social } \\
\text { economy organisations } \\
\text { for unqualified workers, } \\
\text { but also encouraging IT } \\
\text { industry and other high } \\
\text { qualified jobs in sustainable, } \\
\text { and eco-friendly domains). }\end{array}$ & $\begin{array}{l}\text { YES-a powerful } \\
\text { labour market creates } \\
\text { a more diversified } \\
\text { work opportunities, } \\
\text { encourages start-ups, and } \\
\text { increases the competition } \\
\text { on the labour market. }\end{array}$ & $\begin{array}{l}\text { NO - the powerful } \\
\text { group tend to be more } \\
\text { conservative and } \\
\text { oppose to any diversity/ } \\
\text { diversification for } \\
\text { outsiders. }\end{array}$ \\
\hline $\begin{array}{l}\text { NC7. Attracting new } \\
\text { economic agents } \\
\text { into metropolitan } \\
\text { area (in the suburbs) }\end{array}$ & $\begin{array}{l}\text { MAYBE - welcomes the } \\
\text { eco-friendly investors and } \\
\text { economic agents and reject } \\
\text { the others. }\end{array}$ & $\begin{array}{l}\text { YES - a well-planned } \\
\text { and integrated strategy } \\
\text { for the development of } \\
\text { the metropolitan area will } \\
\text { increase the trust of the } \\
\text { economic agents to invest } \\
\text { and the active measures } \\
\text { for maintaining the } \\
\text { environment sustainability } \\
\text { (the development of } \\
\text { industrial parks adequate } \\
\text { equipped). }\end{array}$ & $\begin{array}{l}\text { YES -stimulating } \\
\text { the dynamics of labor } \\
\text { market - ensures new } \\
\text { jobs, available land and } \\
\text { attract work force from } \\
\text { the region (within a 200- } \\
250 \text { km radius, near the } \\
\text { metropolitan area). }\end{array}$ & $\begin{array}{l}\text { MAYBE -if the } \\
\text { dominant group will } \\
\text { need more workers or } \\
\text { other economic agents to } \\
\text { control resources. }\end{array}$ \\
\hline $\begin{array}{l}\text { NC8. Improving } \\
\text { and diversifying } \\
\text { the public } \\
\text { transportation } \\
\text { system (e.g. new } \\
\text { routes for public } \\
\text { transportation, } \\
\text { diversifying } \\
\text { alternative } \\
\text { transportation, car } \\
\text { sharing services) }\end{array}$ & $\begin{array}{l}\text { YES -facilitate and } \\
\text { promote a healthy lifestyle, } \\
\text { a cheaper and sustainable } \\
\text { ways/alternatives for the } \\
\text { present public transport } \\
\text { services. The new } \\
\text { geographical configuration } \\
\text { of the metropolitan } \\
\text { area allows changing } \\
\text { and improving of the } \\
\text { transportation system. }\end{array}$ & $\begin{array}{l}\text { YES - an integrated } \\
\text { development strategy } \\
\text { for the metropolitan area } \\
\text { should stimulate public } \\
\text { investments in alternatives } \\
\text { for the public transport } \\
\text { services, to ensure the } \\
\text { connectivity between } \\
\text { different residential areas. }\end{array}$ & $\begin{array}{l}\text { MAYBE - if stimulating } \\
\text { public-private sustainable } \\
\text { partnerships, or if } \\
\text { economic agents will } \\
\text { develop (new) transport } \\
\text { facilities for their own } \\
\text { employees. }\end{array}$ & $\begin{array}{l}\text { NO - a better } \\
\text { connectivity links } \\
\text { different communities, } \\
\text { but could not divide. }\end{array}$ \\
\hline $\begin{array}{l}\text { NC9. Developing } \\
\text { routes } \\
\text { infrastructure: fast } \\
\text { routes, expanding } \\
\text { the bicycle tracks, } \\
\text { metropolitan train, } \\
\text { commissioning } \\
\text { the Bega navigable } \\
\text { channel }\end{array}$ & $\begin{array}{l}\text { MAYBE- reduces } \\
\text { transport costs, increases } \\
\text { connectivity in the } \\
\text { metropolitan area; but is } \\
\text { questionable if will improve } \\
\text { the quality of life for the } \\
\text { inhabitants and if will } \\
\text { ensure the environment } \\
\text { sustainability. }\end{array}$ & \begin{tabular}{|l|} 
YES - increases the \\
connectivity between \\
residential areas, industrial \\
facilities and urban facilities \\
(saving time currently \\
spent in traffic gems and \\
reduce transportation costs); \\
considerable investments \\
for developing routes \\
infrastructure. \\
\end{tabular} & \begin{tabular}{|l|} 
MAYBE - limited \\
possibility to co-opt \\
private investors for \\
developing routes \\
infrastructure (the \\
legislation states that \\
the routes infrastructure \\
should be in the exclusive \\
administration of the \\
public authorities). \\
\end{tabular} & $\begin{array}{l}\text { NO -is not in the } \\
\text { interest of the dominant } \\
\text { group to develop routes } \\
\text { infrastructure outside of } \\
\text { fortress. }\end{array}$ \\
\hline $\begin{array}{l}\text { NC10. Developing } \\
\text { community centres, } \\
\text { cultural centres } \\
\text { and leisure centres/ } \\
\text { entertainment }\end{array}$ & $\begin{array}{l}\text { YES - it will ensure the } \\
\text {,community life", increases } \\
\text { the role of the civil society } \\
\text { and stimulates an active } \\
\text { citizenship. }\end{array}$ & $\begin{array}{l}\text { YES - stimulates cultural } \\
\text { policies, cultural NGO's, } \\
\text { and cultural projects/events } \\
\text { accessible for the large } \\
\text { public (e.g. represents one } \\
\text { of the pillars of programme } \\
\text { Timissoara - European } \\
\text { Cultural Capital 2021). }\end{array}$ & $\begin{array}{l}\text { YES -increasing } \\
\text { investments into } \\
\text { entertainment facilities, } \\
\text { cultural centres (as } \\
\text { a profit opportunity, } \\
\text { entrepreneurship } \\
\text { development in the } \\
\text { cultural field) }\end{array}$ & $\begin{array}{l}\text { NO-limited access to } \\
\text { culture facilities for a } \\
\text { small elite. }\end{array}$ \\
\hline
\end{tabular}

\section{CONCLUSION}

The Urban Future Methodology represent a very usefully tool with an interdisciplinary background and with a direct applicability for the policies makers. It has some weakness related by the configuration of the participations at the workshop (various groups of stakeholders can generate various outputs). However, the UFM provide a very consistent image about what was made related with the specific subject and, most important, make a consistent prediction about what is possible to happen with all of these in the further decades. 


\section{ACKNOWLEDGMENT}

This work was supported by a grant of the Romanian National Authority for Scientific Research and Innovation, CCCDI-UEFISCDI, project number 66/2017 COFUND-ENSUF-3S RECIPE (1), within PNCDI III "3S RECIPE - Smart Shrinkage Solutions. Fostering Resilient Cities in Inner Peripheries of Europe".

\section{REFERENCES}

Boom van N \& Mommaas H (eds) (2009). Transformation Strategies for Former Industrial Cities. Roterdam: NAi Publishers.

ESPON (2013). Inner Peripheries: a socio-economic territorial specificity. GEOSPECS Final Report 14/01/2013. Geneva: University of Geneva.

Ganser R \& Piro R (eds) (2012). Parallel Patterns of Shrinking Cities and Urban Growth: Spatial Planning for Sustainable Development of City Regions and Rural Areas. Farnham, UK: Ashgate.

Grossmann K, Bontje M, Haase A \& Mykhnenko V (2013). Shrinking cities: notes for the further research agenda, Cities, 35: 221-225.

Haase A, Bernt M, Grossmann K, Mykhnenko V, and Rink D. (2016). Varieties of shrinkage in European cities. European Urban and Regional Studies. 23(1), pp. 86-102.

Langner M \& Endlicher W (eds) (2007). Shrinking Cities: Effects on Urban Ecology and Challenges for Urban Development. Frankfurt: Peter Lang.

Lombardi DR, Leach JM, Rogers CDF et. al. (2012). Designing Resilient Cities: A Guide to Good Practice. Bracknell: IHS BRE Press.

Martinez-Fernandez C, Audirac I, Fol S \& Cunningham-Sabot E (2012). Shrinking cities: urban challenges of globalization, International Journal of Urban and Regional Research, 36 (2): $213-225$.

Mykhnenko V \& Turok I (2008). East European cities - patterns of growth and decline, 19602005, International Planning Studies, 13 (4): 311-342.

Neill WJV \& Schlappa H (2016). Future Directions for the European Shrinking City. Abingdon, UK: Routledge.

Oswalt P (ed) (2005). Shrinking Cities. Vol. 1: International research. Berlin: Hatje Cantz.

Pallagst K, Wiechmann T \& Martinez-Fernandez C (eds) (2014). Shrinking Cities: International Perspectives and Policy Implications. Abingdon, UK: Routledge.

Pike A, MacKinnon D, Coombes, M, Champion T, Bradley D, Cumbers A, Robson L \& Wymer C. (2016). Uneven growth: tackling city decline. York: Joseph Rowntree Foundation.

Richardson HW \& Nam CW (eds) (2014). Shrinking Cities: A Global Perspective. Abingdon, UK: Routledge.

Szeleny I., Andrusz G., Harloe M. (1996) Cities after socialism. Willey and Sons Inc.

Turok I \& Mykhnenko V (2007). The trajectories of European cities, 1960-2005, Cities, 24 (3): 165-182. 